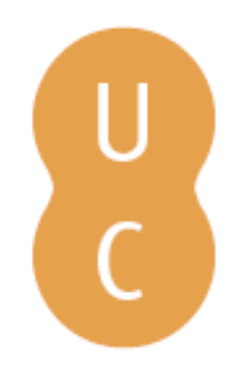

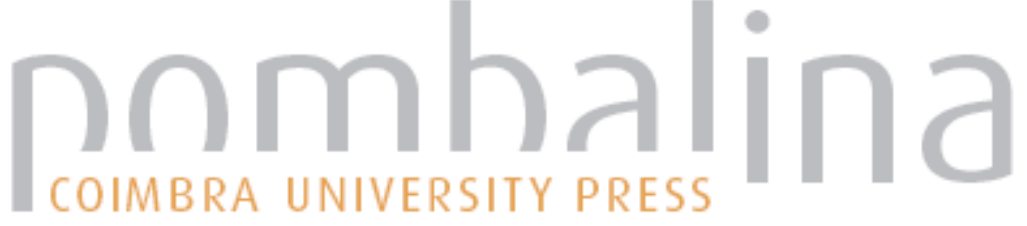

\section{Plastic scintillator detectors for real-time patient dose control}

Autor(es): $\quad$ Antunes, J.; Machado, J.; Peralta, L.

Publicado por: Imprensa da Universidade de Coimbra

URL

persistente: URI:http://hdl.handle.net/10316.2/44456

DOI: $\quad$ DOI:https://doi.org/10.14195/978-989-26-1602-5_13

Accessed : $\quad$ 26-Apr-2023 15:23:49

A navegação consulta e descarregamento dos títulos inseridos nas Bibliotecas Digitais UC Digitalis, UC Pombalina e UC Impactum, pressupõem a aceitação plena e sem reservas dos Termos e Condições de Uso destas Bibliotecas Digitais, disponíveis em https://digitalis.uc.pt/pt-pt/termos.

Conforme exposto nos referidos Termos e Condições de Uso, o descarregamento de títulos de acesso restrito requer uma licença válida de autorização devendo o utilizador aceder ao(s) documento(s) a partir de um endereço de IP da instituição detentora da supramencionada licença.

Ao utilizador é apenas permitido o descarregamento para uso pessoal, pelo que o emprego do(s) título(s) descarregado(s) para outro fim, designadamente comercial, carece de autorização do respetivo autor ou editor da obra.

Na medida em que todas as obras da UC Digitalis se encontram protegidas pelo Código do Direito de Autor e Direitos Conexos e demais legislação aplicável, toda a cópia, parcial ou total, deste documento, nos casos em que é legalmente admitida, deverá conter ou fazer-se acompanhar por este aviso. 


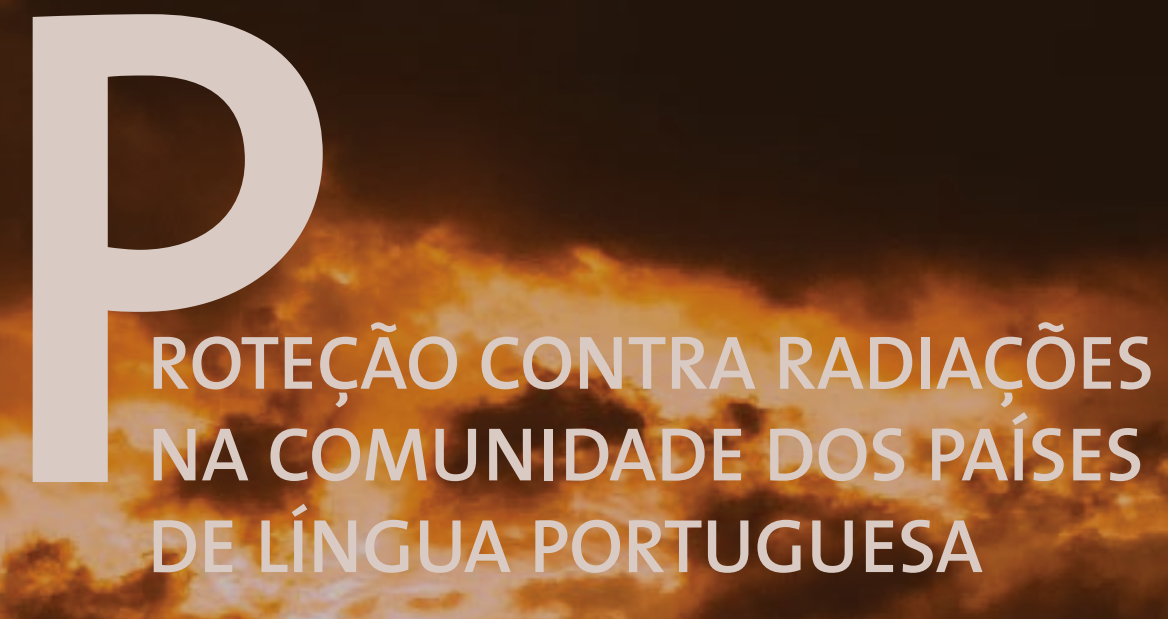

\section{ROTEÇÃO CONTRA RADIAÇÕES NA COMUNIDADE DOS PAÍSES DELINNGUA PORTUGUESA}

Luis Neves (coord.)

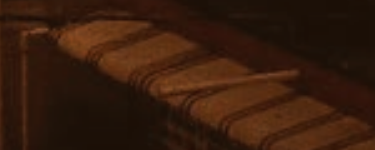




\section{PLASTIC SCINTILLATOR DETECTORS FOR REAL-TIME PATIENT DOSE CONTROL}

\section{detetores de PLÁstico Cintilante PARA Controlo DA DOSE DO PACIENTE EM TEMPO REAL}

J. ANTUNES - joaob@lip.pt (Universidade de Lisboa, Faculdade de Ciências, Departamento de Física, Laboratório de Instrumentação e Física Experimental de Partículas)

J. MACHADO - joana.canejo.machado@gmail.com (Universidade de Lisboa, Faculdade de Ciências, Departamento de Física, Laboratório de Instrumentação e Física Experimental de Partículas)

L. Peralta - luis@lip.pt (Universidade de Lisboa, Faculdade de Ciências, Departamento de Física, Laboratório de Instrumentação e Física Experimental de Partículas)

KEYWORDS: scintillator; dosimetry; tomosynthesis; photodetector.

ABSTRACT: Plastic scintillators detectors (PSDs) have been studied as dosimeters, since they provide a cost-effective alternative to conventional ionization chambers. On the other hand, several articles have reported undesired response dependencies on beam energy and temperature, which enhances the necessity to determine appropriate correction factors. In this study, we exploit the energy and temperature dependencies of BC-404 and BCF-60 scintillators from Saint-Gobain. Measurement and analysis of energy dependency were performed on a Siemens Mammomat tomograph for two different peak kilovoltages: 26 
$\mathrm{kV}$ and $35 \mathrm{kV}$. Both PSD displayed good linearity for each energy considered and almost no energy dependence. Measurements were made at $50 \mathrm{kVp}$ to study the temperature dependence of the scintillators response. In the 0 to $40{ }^{\circ} \mathrm{C}$ range a temperature coefficient less than $0.6 \%{ }^{\circ} \mathrm{C}^{-1}$ was measured.

PALAVRAS-CHAVE: cintilador; dosimetria; tomossíntese; fotodetector.

RESUMO: Os detetores cintiladores de plástico (PSDs) têm sido estudados como dosímetros, uma vez que proporcionam uma alternativa de baixo custo às câmaras de ionização. Por outro lado, vários artigos têm mencionado dependências indesejadas em energia e temperatura, o que reforça a necessidade de determinar fatores de correção apropriados. Neste estudo, foram exploradas as dependências em energia e temperatura dos cintiladores BC404 E BCF-60 da Saint-Gobain. Foram realizadas medições e análises da dependência em energia no Tomógrafo Mammomat da Siemens para dois potenciais de pico: $26 \mathrm{kV}$ e $35 \mathrm{kV}$. Ambos os cintiladores apresentaram uma boa linearidade para cada potencial considerado e baixa dependência da sensibilidade em energia. Foram obtidas medidas do sinal dos cintiladores em função da temperatura sendo a irradiação feita por um tubo de raios-X de $50 \mathrm{kVp}$. No intervalo de temperatura entre 0 e $40{ }^{\circ} \mathrm{C}$ foi obtido um coeficiente de temperatura menor que $0.6 \%{ }^{\circ} \mathrm{C}^{-1}$.

\section{INTRODUCTION}

Despite not being the most lethal cancer type, breast cancer is highly incident among female population worldwide. Particularly, in Portugal 4500 new cases are currently being diagnosed each year, 
in a universe of about 5 million women. Breast cancer diagnose techniques, such as mammography and tomosynthesis, make use of X-ray beams with kilovoltage peaks ranging from $26 \mathrm{kV}$ to 35 $\mathrm{kV}$ to obtain digital images of the organ.

Tomosynthesis constitutes a diagnose method that enables breast reconstruction from different radiographic projections. This technique uses ionizing radiation and so it is necessary to monitor the dose delivered to the patient avoiding over-exposure (Dobbins et al 2003).

In recent years there has been increasing interest in the use of plastic scintillation detectors (PSD) due to its favorable characteristics compared with other systems (Lambert et al. 2006). In spite of this, there are no commercial systems in use for radiology application. Plastic scintillator-based dosimeters exhibit a linear relation between deposited dose and produced signal, have good sensitivity and dose rate independence, possibility of direct readout and can be made quite small (Beddar et al. 2004, Beierholm et al. 2008). It has been shown that some plastic scintillators have small temperature dependence (Nowotny et al. 2009, Whelehan 2010 , Buranurak et al. 2013).

Diagnostic radiology typically uses X-rays beams between 25 and $150 \mathrm{kVp}$ (Lessard et al. 2012). Studies of scintillator properties in this range have been done in recent years (Peralta et al. 2014, Lambert et al. 2006). These works have shown that PSDs are good candidates for real-time dosimetry in limited energy ranges. Based on this concept a PSD with a photomultiplier (PMT) readout was developed for radiology application. In particularly this device was tested on a beam delivered by a Tomosynthesis machine. The PSD consists of a blue-emitting, plastic scintillator coupled to a clear PMMA optical fiber read by a photomultiplier (Hamamatsu R647P). The signal produced by the photomultiplier feeds a charge amplifier. 
The aim of this study is to validate the device for tomosynthesis applications (26-35 kVp) using two plastic scintillators, BC404 and BCF-60. Previous prototype tests were conducted in the laboratory using $50 \mathrm{kVp}$ X-ray beam followed by clinical validation on Mammomat Inspiration Tomograph from Siemens.

\section{METHODS}

\subsection{Dosimeter}

Two dosimeters were built and evaluated, one using BC- 404 scintillator and the other using BCF-60 scintillator. The choice to use these scintillators was based on previous studies made on the scintillators performances (Peralta et al. 2014). The signal is transmitted through a clear PMMA optical fiber, $2 \mathrm{~mm}$ in diameter (ESKA SK-80 from Mitsubishi), to a PMT (Hamamatsu R647P). The optical fiber was placed inside a black plastic jacket for isolation from room light. The PMT signal is amplified by charge amplifier

read by a digital voltmeter. The charge amplifier was developed by our group and is based on the LCM6001 ultra-low input current integrated amplifier.

Dose measurements were made in a slab PMMA phantom 10.2 $\times 10.8 \mathrm{~cm}^{2}$ on the side and $1.5 \mathrm{~cm}$ thick each slab. The phantom is assembled for the measurements with 3 slabs in a total thickness of $4.5 \mathrm{~cm}$. Special slabs with holes for holding the PSD or an ionization chamber were foreseen. For absolute dose measurements, a Farmer ionization chamber (PTW TM30013) read by a PTW UNIDOS E electrometer was used.

\subsection{Temperature dependence}

Ideally, the response from the dosimeter should be constant for a sufficiently wide range of temperatures. However, several 
studies suggest that dosimeters present temperature dependency (Buranurak et al. 2013, Wootton et al. 2013). In order to correct the dosimeter reading value, it becomes important to study the scintillator's temperature dependence.

For the selected scintillators the study of the signal temperature dependence was made. The PSD was placed inside a beaker filled with distilled water. The setup was irradiated with a 50 $\mathrm{kVp}$ X-ray beam delivered by a clinical tube. The beaker was gradually heated from 0 to $40{ }^{\circ} \mathrm{C}$ with the help of a heating pad. Temperature readings were performed using a probe connected to a digital voltmeter (Tenma 72-7730). The PSD was coupled to the PMT readout by the UNIDOS E electrometer. The beam stability was controlled using a X-ray monitor based on the $\mathbf{S 8 1 9 3}$ Hamamatsu photodiode.

\subsection{Clinical tests}

Tomosynthesis is a technique that improves upon conventional mammography allowing a set of reconstructed planes acquired during a single motion of the X-ray tube (Dobbins et al 2003). Clinical tests were conducted at Hospital da Luz in Lisbon with a Mammomat Inspiration Tomograph from Siemens. The Mammomat Inspiration Tomograph X-ray tube has molybdenum and tungsten targets and molybdenum and rhodium filters (Whelehan 2010). Acquisitions were made at 26 and $35 \mathrm{kVp}$ using the molybdenum anode and rhodium filter for a charge of $56 \mathrm{mAs}$.

The slab phantom was placed on the selenium detector with the compression plate on top of the phantom. The slabs holding PSD or ionization chamber could be moved to three different positions allowing three different dose measurements. 


\section{RESULTS}

\subsection{Temperature dependence}

There is a clear dependence on temperature of BCF-60 and BC-404 scintillator. Figure 1 shows the signal variation in the two scintillators as a function of temperature. In each case a linear fit was performed to the data in measured range. For the BC- 404 scintillator a temperature coefficient (Buranurak et al. 2013) of $(-0.36+-0.01) \%{ }^{\circ} \mathrm{C}^{-1}$ was obtained while for the BCF-60 a slightly higher $(0.6 \%+-0.1) \%{ }^{\circ} \mathrm{C}^{-1}$ was seen. A recent study by Buranurak et al. 2013, shows a variation of approximately $0.58 \%{ }^{\circ} \mathrm{C}^{-1}$ increase in the signal read by the BCF-60 scintillator compatible with our results.

A study by Wootton \& Beddar 2013, obtained a slightly lower variation of $0.50 \%$ for the same scintillator still compatible within experimental uncertainties. All three studies were made using 50 $\mathrm{kVp}$ X-ray beams. On what concerns to BC- 404 scintillator there is no other study that we can compare with.

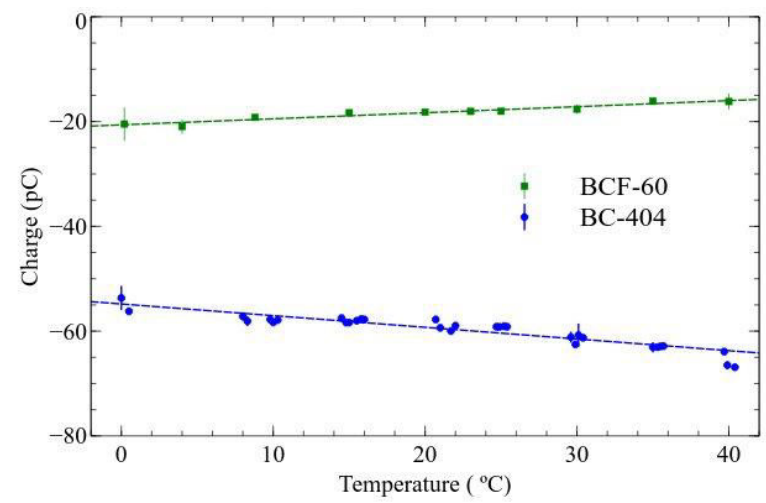

Figure 1. Signal from PSDs measured by electrometer as a function of temperature for BCF- 60 and BC- 404 scintillators. The straight lines are linear fits to data points. 


\subsection{Clinical tests}

The results obtained in the clinical tests are presented in Figure 2 (BCF-60) (BC-404) for the PSD signal as a function of dose measured by the ionization chamber, and for two X-ray tube voltages. Experimental uncertainties are lower than $2 \%$ both for PSD signal and ionization chamber. For each set of values, a linear fit was performed to the data and the slope (sensitivity) extracted. Results are presented in table 1.

For the BC-404 scintillator the straight line slopes for 26 and $35 \mathrm{kV}$ are identical within the experimental uncertainties. We thus conclude that the energy dependence of the PSD is small in the measurement range. Comparing the slopes for both scintillators we conclude that BC-404 has a better performance.

Table 1. Straight line slope from linear fit to PSDs signal as a function of dose inside a PMMA phantom when irradiated at Mammomat Inspiration Tomograph.

\begin{tabular}{cccc}
\hline \multicolumn{2}{c|}{ BC-404: Slope $(\mathrm{V} / \mathrm{mGy})$} & \multicolumn{2}{c}{ BCF-60: Slope (V/mGy) } \\
\hline $26 \mathrm{kV}$ & $35 \mathrm{kV}$ & $26 \mathrm{kV}$ & $35 \mathrm{kV}$ \\
\hline $0.81+-0.01$ & $0.82+-0.02$ & $0.281+-0.005$ & $0.267+-0.006$ \\
\hline
\end{tabular}

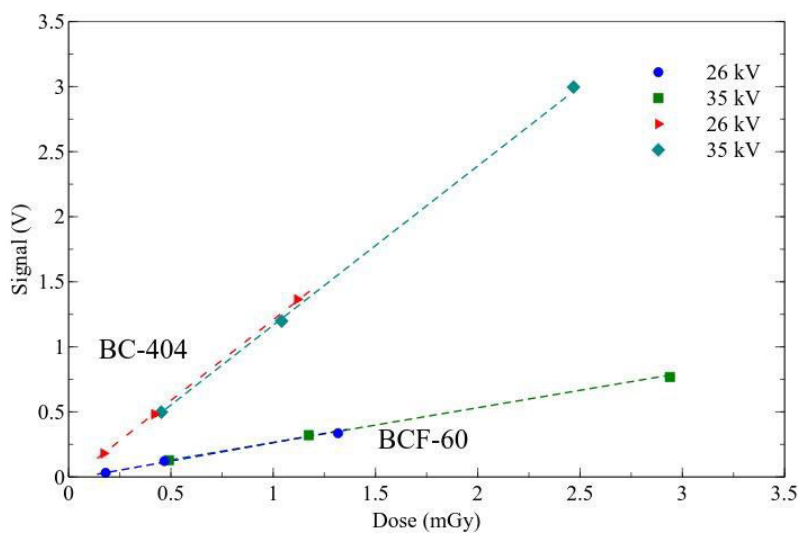

Figure 2. Signal from PSDs as a function of dose measured by an ionization chamber in a PMMA phantom irradiated at the Mammomat Inspiration Tomograph. Results are presented for BCF-60 and BC-404 scintillators and two $\mathrm{X}$-ray tube peak voltages. 


\section{CONCLUSION}

A dosimetry system based on plastic scintillator has been successfully tested for 26 and $35 \mathrm{kVp}$ in tomosynthesis system. The PSD energy dependence of the sensitivity is small in the measured range making it suitable for dose measurements in this radiological application. PSDs provide a low cost alternative for dose monitoring, and may be manufactured in a wide variaty of shapes and dimensions.

\section{Acknowledgements}

This work was founded by Project PTDC/BBB-IMG/3310/2012 and project “QREN RAD4LIFE” CENTRO-07-ST24-FEDER-002007. We are thankful to Hospital da Luz in Lisbon for the opportunity of performing the clinical tests and to the LIP workshop in Coimbra for the manufacture of the phantom. We also acknowledge the assistance of Prof. Nuno Matela on the data acquisition.

\section{References}

J.T. Dobbins et al., "Digital tomosynthesis of the chest for lung nodule detection: Interim sensitivity results from an ongoing NIH-sponsored trial", Phys. Med. Biol. 48 (2003) 2554-2557.

J. Lambert et al. "A plastic scintillation dosimeter for high dose rate brachytherapy", Phys. Med. Bio. 51, (2006) 5505-5516.

S. Beddar, N. Suchowerska, S.H. Law, "Plastic scintillation dosimetry for radiation therapy: minimizing capture of Cerenkov radiation noise", Phys. Med. Biol. 49 (2004) 783 .

A.R. Beierholm, C.E. Andersen, L.R. Lindvold, F. Kjær-Kristoffersen, J. Medin, "A comparison of BCF-12 organic scintillators and Al2O3:C crystals for real-time medical dosimetry", Radiat. Meas. 43 (2008) 898.

R. Nowotny, A. Taubeck, "A method for the production of composite scintillators for dosimetry in diagnostic radiology", Phys. Med. Biol. 54 (2009) 1457.

P. Whelehan, Evaluation and Clinical Assessment of the Siemens Mammomat Inspiration Full Field Direct Digital Mammography Unit. NHSBSP Equipment Report (May 2010). 
S. Buranurak , C.E. Andersen et al., "Temperature variations as a source of uncertainty in medical fiber-coupled organic plastic scintillator dosimetry", Radiation Measurements 56 (2013) 307-311.

F. Lessard et al.,"Validating plastic scintillation detectors for photon dosimetry in the radiologic energy range", Med. Phys. 39 5308-16 (2012).

L. Peralta, F. Rêgo, "Response of plastic scintillators to low-energy photons", Phys. Med. Biol. 59 (2014) 4621-4633.

L.Wootton, S. Beddar, "Temperature dependence of BCF plastic scintillation detectors", Phys. Med. Biol. 58 (2013) 2955-2967. 